\title{
Reanalysis of microarray data reveals insights into altered transcriptional activity of T helper 17 and regulatory $T$ cell signaling in psoriasis
}

This article was published in the following Dove Press journal:

Psoriasis: Targets and Therapy

II December 2013

Number of times this article has been viewed

\author{
Iman Kotb' \\ Caroline Meharg² \\ Robert N Barker ${ }^{1}$ \\ Anthony Ormerod' \\ 'Institute of Medical Sciences, \\ University of Aberdeen, Aberdeen, \\ Scotland, UK; ${ }^{2}$ Institute for Global \\ Food Security, Queen's University, \\ Belfast, Northern Ireland
}

\begin{abstract}
Identifying differential expression of genes in psoriatic and healthy skin by microarray data analysis is a key approach to understand the pathogenesis of psoriasis. Analysis of more than one dataset to identify genes commonly upregulated reduces the likelihood of false positives and narrows down the possible signature genes. Genes controlling the critical balance between $\mathrm{T}$ helper 17 and regulatory $\mathrm{T}$ cells are of special interest in psoriasis. Our objectives were to identify genes that are consistently upregulated in lesional skin from three published microarray datasets. We carried out a reanalysis of gene expression data extracted from three experiments on samples from psoriatic and nonlesional skin using the same stringency threshold and software and further compared the expression levels of 92 genes related to the Thelper 17 and regulatory $\mathrm{T}$ cell signaling pathways. We found 73 probe sets representing 57 genes commonly upregulated in lesional skin from all datasets. These included 26 probe sets representing 20 genes that have no previous link to the etiopathogenesis of psoriasis. These genes may represent novel therapeutic targets and surely need more rigorous experimental testing to be validated. Our analysis also identified 12 of 92 genes known to be related to the T helper 17 and regulatory $\mathrm{T}$ cell signaling pathways, and these were found to be differentially expressed in the lesional skin samples.
\end{abstract}

Keywords: psoriasis, gene array analysis, gene expression profiling

\section{Introduction}

Psoriasis is a common, chronic, inflammatory, relapsing skin disease mediated by $\mathrm{T}$ cells, dendritic cells, and several inflammatory cytokines. ${ }^{1,2}$ Recent advances in our knowledge of mechanisms linking innate and adaptive immunity have led to reconsideration of the roles of key players in the pathogenesis of the disease with many uncertainties. ${ }^{3}$

Studies of gene expression profiling provide valuable insights into the pathomechanisms involved in psoriasis. The transcriptome from skin biopsies was previously analyzed on microarrays using the 7,000-oligonucleotide array HU6800, the approximately 12,600 element array U95A, the approximately 63,000 probe sets Affymetrix U95A-E arrays, and cDNA arrays. ${ }^{4-7}$ As a result, a number of changes in gene and/or protein expression have been detected in psoriasis, eg, interleukin (IL)-1 and tumor necrosis factor alpha $(\mathrm{TNF}-\alpha)$, which were reported to be upregulated with subsequent activation of the NF- $\kappa$ B pathway. ${ }^{5}$ It was also noted that Wnt5a and other genes involved in the Wnt signaling pathway are differentially expressed in psoriatic plaques. However, their functional contribution to the pathophysiology of psoriasis needs to be elaborated. ${ }^{8}$ Recently, concerns regarding false positives and/or missing
Correspondence: Anthony Ormerod Institute of Medical Sciences, University of Aberdeen, Ashgrove Road West, Aberdeen AB25 2ZD, Scotland, UK Tel +440I2 24553955

Fax +44 01224550555

Email a.d.ormerod@abdn.ac.uk 
key signals from microarray data have arisen due to the large size of the data output, the background noise inherent in the technology, and the financial constraints on the number of replicates. ${ }^{9}$ As a result, reanalysis of published microarray data has become a useful extension of the technology.

Recent studies have shown the crucial role of the $\mathrm{T}$ helper $17\left(\mathrm{~T}_{\mathrm{H}} 17\right)$ cell population in development of the disease. ${ }^{10} \mathrm{~T}_{\mathrm{H}} 17$ cells are activated by the dendritic cell cytokine IL-23, can produce IL-17, IL-22, and TNF- $\alpha$, and have many other downstream proinflammatory effects. ${ }^{11}$ Conversely, $\mathrm{T}$ regulatory $\left(\mathrm{T}_{\mathrm{Reg}}\right)$ cells suppress effector $\mathrm{T}$ cell responses and prevent their potentially pathogenic effects. ${ }^{12}$ $\mathrm{T}_{\text {Reg }}$ cells are characterized by expression of the transcription factor Forkhead box P3. Differentiation of both $\mathrm{T}_{\mathrm{H}} 17$ and $\mathrm{T}_{\text {Reg }}$ cells can require transforming growth factor-beta, and the balance between these cells may be mediated by IL- 6 . The production of IL- 6 during inflammatory reactions makes Forkhead box $\mathrm{P}^{+} \mathrm{T}_{\text {Reg }}$ nonfunctional and allows effector cells to induce inflammation in the target organ. ${ }^{13,14}$ However, much remains to be elucidated concerning the relationship between proinflammatory and regulatory cells. ${ }^{10}$

This study aims to comprehensively reanalyze microarray gene expression data extracted from three different experiments deposited in the GEO datasets, ${ }^{8,15,16}$ according to the same criteria. All experiments included skin biopsies from lesional and nonlesional skin, while only two experiments include additional samples from healthy control skin. By reporting genes that are found to be upregulated as a result of the disease in more than one experiment, the possibility of false positives is reduced and the output gene list is refined. We also related our findings to the expression profile of 92 genes (Table 1) involved in the $\mathrm{T}_{\mathrm{H}} 17$ and $\mathrm{T}_{\mathrm{Reg}}$ regulatory pathways.

\section{Materials and methods Gene microarray experiments}

Data from three experiments with GEO accession numbers, GSE6710, GSE13355, and GSE14905, were extracted from the free PubMed domain (http://www.ncbi.nlm.nih.gov/ gds?term=psoriasis) for further analysis. The GSE6710 experiment ${ }^{8}$ includes data from lesional and nonlesional skin samples from 13 individuals with psoriasis and used parent platform GPL96 Affymetrix Human Genome U133A GeneChip $^{\circledR}$ (Affymetrix, Santa Clara, CA, USA). In the GSE13355 experiment, ${ }^{15}$ the parent platform GPL570 Affymetrix Human Genome U133 PLUS 2.0 GeneChip was used and a total of 180 skin samples were profiled, encompassing biopsies from the healthy skin of 64 control subjects and biopsies from the involved and uninvolved skin of 58 patients
Table I Genes involved in the T helper I 7 and regulatory T cell signaling pathways that were specifically interrogated in our analysis

\begin{tabular}{ll}
\hline Surface molecules & CD28, CD34, CD3D, CD3E, CD3G, \\
& CD4, CD25, CDI27, CD40LG, CD8A, \\
& ICAMI, ICOS, ISG20, CTLA4 \\
Chemokines & CCLI, CCL2, CCL20, CCL22, CCL7, \\
& CD247, CX3CLI, CXCLI, CXCLI2, \\
& CXCL2, CXCL5, CXCL6, IL8, MMPI3, \\
& MMP3, MMP9, CCR4, CCR6 \\
& CSF2, CSF3, IFNG, ILI0, ILI2B, ILI3, ILI5, \\
Cytokines & ILI7A, ILI7C, ILI7D, ILI7F, ILI8, ILIA, \\
& ILIB, IL2, IL2I, IL22, IL23A, IL25, IL27, \\
& IL3, IL4, IL5, IL6, TGFBI, TNFA, TNFB \\
& ILI2RBI, ILI 2RB2, ILI7RB, ILI7RC, \\
Cytokine receptors & ILI7RD, ILI7RE, IL23R, IL6R, IL7R \\
Signaling pathway molecules & CACYBP, CEBPB, CLEC7A, EDG I, \\
and transcriptional factors & FOXP3, GATA3, JAKI, JAK2, NFATC2, \\
& NFKBI, RORC, SOCSI, SOCS3, STAT3, \\
& STAT4, STAT5A, STAT6, SYK, TBX2I, \\
& TIRAP, TLR4, TRAF6, YYI, T-BET \\
\hline
\end{tabular}

with psoriasis. In the GSE14905 experiment, ${ }^{16}$ the parent platform GPL570 Affymetrix Human Genome U133 Plus 2.0 GeneChip was used and a total of 82 skin samples were profiled (21 normal, 28 uninvolved skin, and 33 lesional skin).

\section{Microarray data analyses}

Data files from the above experiments were analyzed with GeneSpring GX11 software (Agilent Technologies, Santa Clara, CA, USA). Ambiguous samples (three samples from GSE6710 and one sample from each of GSE13355 and GSE14905) were excluded by running quality control on each dataset. The data were filtered by expression within the 20-100th percentile, log-transformed, normalized using the Robust Multichip Average algorithm, and baseline converted to the median of all samples. Differential expression in lesional versus nonlesional skin samples was compared using paired Student's $t$-test statistics with a $P$-value cutoff $\leq 0.05$ and a fold change $\geq 2.0$. To discern further the biological meaning of the output gene lists, we functionally annotated significantly expressed genes on human Kegg pathways using Database for Annotation, Visualization and Integrated Discovery (DAVID) ${ }^{17}$ version 6.7 and the HT Human Genome U133 Plus set as background.

For identification of possible interactions between genes of potential importance for the development of psoriasis, network analysis was performed with NetBox 1.0 (cBio, Memorial Sloan-Kettering Cancer Center, New York, NY, USA) (http://cbio.mskcc.org/tools/netbox/netbox.tar.gz). This tool uses human interactions derived from literature- 
curated data sources for prediction of interaction of genes in a submitted gene list. NetBox is preloaded with a human interaction network derived from four literature-curated data sources, including the Human Protein Reference Database, ${ }^{18}$ Reactome, ${ }^{19,20}$ NCI-Nature Pathway Interaction Database, ${ }^{21}$ and Memorial Sloan-Kettering Cancer Center Cancer Cell Map, and provides the netAnalyse.py method for network analysis, which was described by Cerami et $\mathrm{al}^{22}$ in 2010 . The netAnalyse.py method settings applied during analysis were shortest path threshold $=1$ and $P$-value threshold $=0.05$. The resultant networks were then imported into Cytoscape for further editing and analysis. ${ }^{23}$

\section{Results}

Reanalysis of three published microarray datasets ${ }^{8,15,16}$ revealed a number of probe sets that are differentially expressed (upregulated and/or downregulated) in psoriatic lesional versus nonlesional skin from each experiment, and the Venn diagram in Figure 1 illustrates the intersections between the three experiments. In general, a total of 73 probe sets representing 57 genes were found common to the three datasets and were significantly upregulated in the psoriatic lesions (Figure 1, with a complete list in Tables S1 and S2). Of these probe sets, only 26 representing 20 genes have no previous reported link to the etiopathogenesis of psoriasis (Table S2).

We then studied the transcriptional activity underlying the dynamic interplay between the $\mathrm{CD}^{+} \mathrm{T}_{\mathrm{H}} 17$ and $\mathrm{CD}^{+} \mathrm{CD} 25^{\text {high }}$ FoxP $3{ }^{+} \mathrm{T}_{\mathrm{Reg}}$ cell lineages in the skin of psoriatic patients from the three above experiments. This interplay has recently been linked to the etiopathogenesis of psoriasis and some other autoimmune diseases. ${ }^{10,24}$
A list of 92 genes (Table 1) that are likely to be involved in the $T_{H} 17$ and $T_{\text {Reg }}$ signaling pathways was prepared. In the first instance, we searched for the differential expression of these genes in the three experiments.

A total of 12 genes were found to be differentially expressed (upregulated/downregulated) in the lesional skin samples with a false discovery rate of $<0.01$ and an absolute fold change $>2$ in at least one of the datasets (Tables 2-4). In the data extracted and analyzed from the GSE6710 experiment, ${ }^{8}$ five probe sets representing four genes were found to be differentially expressed in the psoriatic lesions, with CD34 being the only example to be downregulated (Table 2). The corresponding profile for the data from GSE13355 15 is a total of nine probe sets/genes that are all upregulated in the lesional versus nonlesional skin (Table 3 ). In the GSE14905 dataset, ${ }^{16}$ a total of 12 probe sets representing 11 genes were found to be significantly upregulated in the lesional versus nonlesional skin (Table 4).

Network analysis was performed on the significantly changed genes reported in Tables 2-4, S1, and S2. Genes associated with $\mathrm{T}_{\mathrm{H}} 17 / \mathrm{T}_{\mathrm{Reg}}$ reported in Table 1 were added to this list to aid identification of a possible connection between these genes. The resultant network was then imported into Cytoscape for further analysis. ${ }^{23}$ In order to depict possible interactions between genes reported in Tables 2-4, S1, and $\mathrm{S} 2$, the nodes for these genes in the network were enlarged and were colored orange, red (upregulated in psoriasis), or green (downregulated in psoriasis). Identified direct interactions of these genes, which were predicted by the network analysis, were marked as connecting red lines between these nodes (Figure 2).

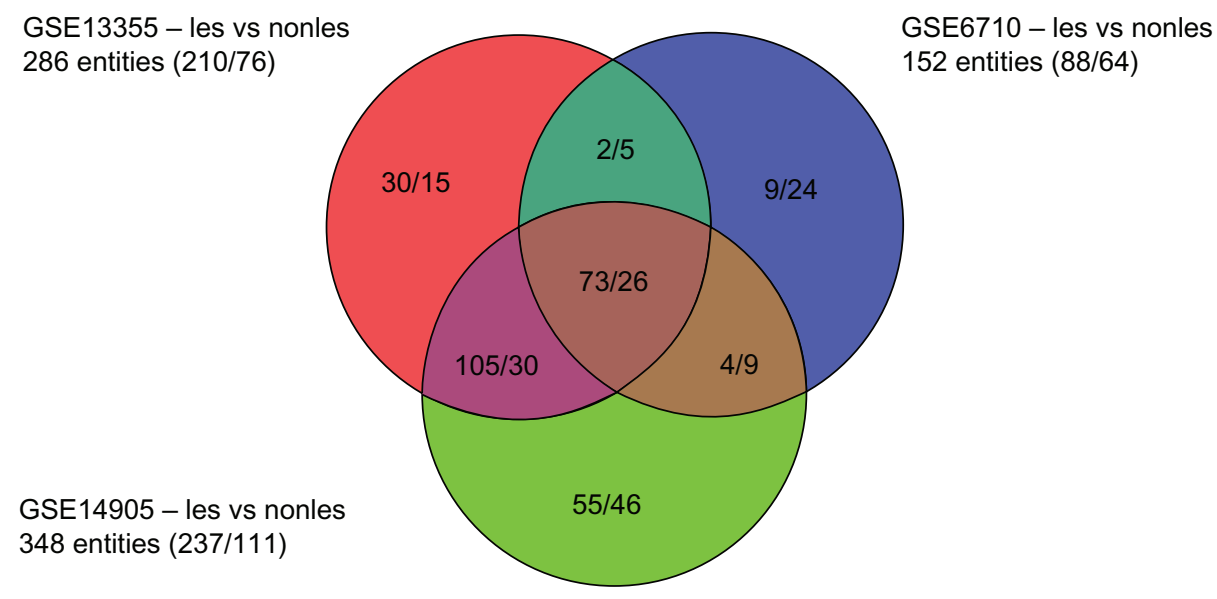

Figure I Venn diagram illustrates the number of probe sets that show significant higher expression/number of those showing significant lower expression in lesional versus nonlesional skin from the three experiments, ie, GSE67I0 (upper right circle), GSEI 3355 (upper left circle), and GSEI4905 (lower circle). The intersecting regions represent probe sets that are common in the specific experiments.

Abbreviations: GSE, GeneSys Export file; les, lesional; vs, versus; nonles, nonlesional. 
Table 2 Fold changes ( $\log _{2}$ transformed) and corrected $P$-values (calculated by GeneSpring GX) for genes involved in the $T$ helper 17 and regulatory $T$ cell signaling pathways and upregulated and/or downregulated

\begin{tabular}{|c|c|c|c|c|}
\hline \multirow[t]{2}{*}{ Probe ID } & \multirow[t]{2}{*}{$\begin{array}{l}\text { Gene } \\
\text { symbol }\end{array}$} & \multirow[t]{2}{*}{$\begin{array}{l}\text { Gene } \\
\text { description }\end{array}$} & \multicolumn{2}{|c|}{$\begin{array}{l}\text { Lesional versus } \\
\text { nonlesional }\end{array}$} \\
\hline & & & $\begin{array}{l}\log _{2} \text { fold } \\
\text { change }\end{array}$ & $\begin{array}{l}\text { Corrected } \\
P \text {-value }\end{array}$ \\
\hline 20899I_at & STAT3 & $\begin{array}{l}\text { Signal transducer } \\
\text { and activator of } \\
\text { transcription } 3\end{array}$ & 1.229 & $2.84 \mathrm{E}-05$ \\
\hline 208992_s_at & STAT3 & $\begin{array}{l}\text { Signal transducer } \\
\text { and activator of } \\
\text { transcription } 3\end{array}$ & 1.469 & 4.07E-07 \\
\hline 209543_s_at & CD34 & $\begin{array}{l}\text { Cluster of } \\
\text { differentiation } 34\end{array}$ & -1.046 & I.67E-05 \\
\hline 202859_x_at & IL8 & Interleukin 8 & 2.686 & I.17E-05 \\
\hline 205476_at & CCL20 & $\begin{array}{l}\text { C-C motif } \\
\text { ligand } 20\end{array}$ & 1.932 & $7.39 \mathrm{E}-07$ \\
\hline
\end{tabular}

Notes: Positive and negative values of fold changes indicate upregulation and downregulation, respectively. Data were extracted and analyzed from the GSE6710 experiment. ${ }^{8}$

Network analysis was also performed on significant differentially expressed genes in each of the three data sets investigated, ie, GSE6710, GSE14905, and GSE13355 ( significant $=$ two-fold upregulated $/$ downregulated in lesional versus nonlesional skin with a false discovery rate $<0.05$ ).

Table 3 Fold changes ( $\log _{2}$ transformed) and corrected $P$-values (calculated by GeneSpring GX) for genes involved in the Thelper 17 and regulatory $\mathrm{T}$ cell signaling pathways and upregulated and/or downregulated

\begin{tabular}{|c|c|c|c|c|}
\hline \multirow[t]{2}{*}{ Probe ID } & \multirow[t]{2}{*}{$\begin{array}{l}\text { Gene } \\
\text { symbol }\end{array}$} & \multirow[t]{2}{*}{$\begin{array}{l}\text { Gene } \\
\text { description }\end{array}$} & \multicolumn{2}{|c|}{$\begin{array}{l}\text { Lesional versus } \\
\text { nonlesional }\end{array}$} \\
\hline & & & $\begin{array}{l}\log _{2} \text { fold } \\
\text { change }\end{array}$ & $\begin{array}{l}\text { Corrected } \\
\text { P-value }\end{array}$ \\
\hline 208992_s_at & STAT3 & $\begin{array}{l}\text { Signal transducer } \\
\text { and activator of } \\
\text { transcription } 3\end{array}$ & 1.132 & $1.02 \mathrm{E}-28$ \\
\hline 39402_at & ILIB & Interleukin I beta & 1.104 & $9.79 \mathrm{E}-23$ \\
\hline 205476_at & CCL20 & $\begin{array}{l}\text { C-C motif } \\
\text { ligand } 20\end{array}$ & 2.889 & $2.99 E-35$ \\
\hline 205798_at & IL7R & $\begin{array}{l}\text { Interleukin } 7 \\
\text { receptor }\end{array}$ & 1.266 & $6.91 \mathrm{E}-16$ \\
\hline 20786I_at & CCL22 & $\begin{array}{l}\text { C-C motif } \\
\text { chemokine } 22\end{array}$ & 1.032 & $7.31 \mathrm{E}-25$ \\
\hline 209774_x_at & CXCL2 & $\begin{array}{l}\text { Chemokine } \\
\text { C-X-C motif } \\
\text { ligand } 2\end{array}$ & $1.83 \mathrm{I}$ & I.27E-24 \\
\hline 211506_s_at & IL8 & Interleukin 8 & 2.582 & $2.64 \mathrm{E}-17$ \\
\hline 216598_s_at & CCL2 & $\begin{array}{l}\text { Chemokine C-C } \\
\text { motif ligand } 2\end{array}$ & 1.436 & $1.95 \mathrm{E}-18$ \\
\hline 203936_s_at & MMP9 & $\begin{array}{l}\text { Matrix } \\
\text { metallopeptidase } 9\end{array}$ & 1.486 & $6.18 \mathrm{E}-29$ \\
\hline
\end{tabular}

Notes: Positive and negative values of fold changes indicate upregulation and downregulation, respectively. Data are extracted and analyzed from the GSEI3355 experiment. $^{15}$
Table 4 Fold changes ( $\log _{2}$ transformed) and corrected $P$-values (calculated by GeneSpring GX) for genes involved in the Thelper 17 and regulatory $\mathrm{T}$ cell signaling pathways and upregulated and/or downregulated

\begin{tabular}{|c|c|c|c|c|}
\hline \multirow[t]{2}{*}{ Probe ID } & \multirow[t]{2}{*}{$\begin{array}{l}\text { Gene } \\
\text { symbol }\end{array}$} & \multirow[t]{2}{*}{$\begin{array}{l}\text { Gene } \\
\text { description }\end{array}$} & \multicolumn{2}{|c|}{$\begin{array}{l}\text { Lesional versus } \\
\text { nonlesional }\end{array}$} \\
\hline & & & $\begin{array}{l}\text { Log }_{2} \text { fold } \\
\text { change }\end{array}$ & $\begin{array}{l}\text { Corrected } \\
P \text {-value }\end{array}$ \\
\hline 20899I_at & STAT3 & $\begin{array}{l}\text { Signal transducer } \\
\text { and activator of } \\
\text { transcription } 3\end{array}$ & 1.169 & 4.I7E-I5 \\
\hline 208992_s_at & STAT3 & $\begin{array}{l}\text { Signal transducer } \\
\text { and activator of } \\
\text { transcription } 3\end{array}$ & 1.247 & $1.04 \mathrm{E}-13$ \\
\hline 39402_at & ILIB & Interleukin I beta & 1.191 & 5.86E-09 \\
\hline 205758_at & CD8A & $\begin{array}{l}\text { Cluster of } \\
\text { differentiation 8a }\end{array}$ & 1.001 & 3.5 IE-II \\
\hline 202859_x_at & IL8 & Interleukin 8 & 3.606 & $5.22 \mathrm{E}-\mathrm{II}$ \\
\hline 205476_at & CCL20 & $\begin{array}{l}\text { C-C motif } \\
\text { ligand } 20\end{array}$ & 2.664 & $4.69 \mathrm{E}-15$ \\
\hline 205798_at & IL7R & $\begin{array}{l}\text { Interleukin } 7 \\
\text { receptor }\end{array}$ & 2.012 & $1.03 \mathrm{E}-12$ \\
\hline 20786I_at & CCL22 & $\begin{array}{l}\text { C-C motif } \\
\text { chemokine } 22\end{array}$ & 1.210 & $4.22 \mathrm{E}-10$ \\
\hline 209774_x_at & $\mathrm{CXCL2}$ & $\begin{array}{l}\text { Chemokine } \\
\text { C-X-C motif } \\
\text { ligand } 2\end{array}$ & $\mathrm{I} .870$ & $7.91 \mathrm{E}-12$ \\
\hline 216598_s_at & CCL2 & $\begin{array}{l}\text { Chemokine C-C } \\
\text { motif ligand } 2\end{array}$ & 1.345 & $2.62 \mathrm{E}-07$ \\
\hline 213539_at & CD3D & $\begin{array}{l}\text { T cell surface } \\
\text { glycoprotein } \\
\text { CD3 delta chain }\end{array}$ & 1.282 & $3.04 \mathrm{E}-1 \mathrm{I}$ \\
\hline 203936_s_at & MMP9 & $\begin{array}{l}\text { Matrix } \\
\text { metallopeptidase } 9\end{array}$ & 1.600 & $3.96 \mathrm{E}-1 \mathrm{I}$ \\
\hline
\end{tabular}

Notes: Positive and negative values of fold changes indicate upregulation and downregulation, respectively. Data are extracted and analyzed from the GSEI 4905 experiment. ${ }^{16}$

Nodes in these networks were colored according to fold change (green downregulated, yellow-orange-red upregulated) and size of the node indicates relative significance (larger being more significant) (Figures S1-S3).

\section{Discussion}

This study confirmed previously reported and newly identified changes in gene transcription in psoriatic skin that might contribute to the etiopathogenesis. Our approach was to reanalyze the microarray raw data deposited in the GEO datasets from three different experiments. ${ }^{8,15,16}$ Simple comparison of the available published differentially expressed genes from these studies was avoided. This was to ensure consistent analyses rather than rely on different statistical tests and to enforce the same stringency threshold. ${ }^{25,26}$ The use of data extracted from more than one experiment filters out false positives and narrows down the list of genes that show a significantly 


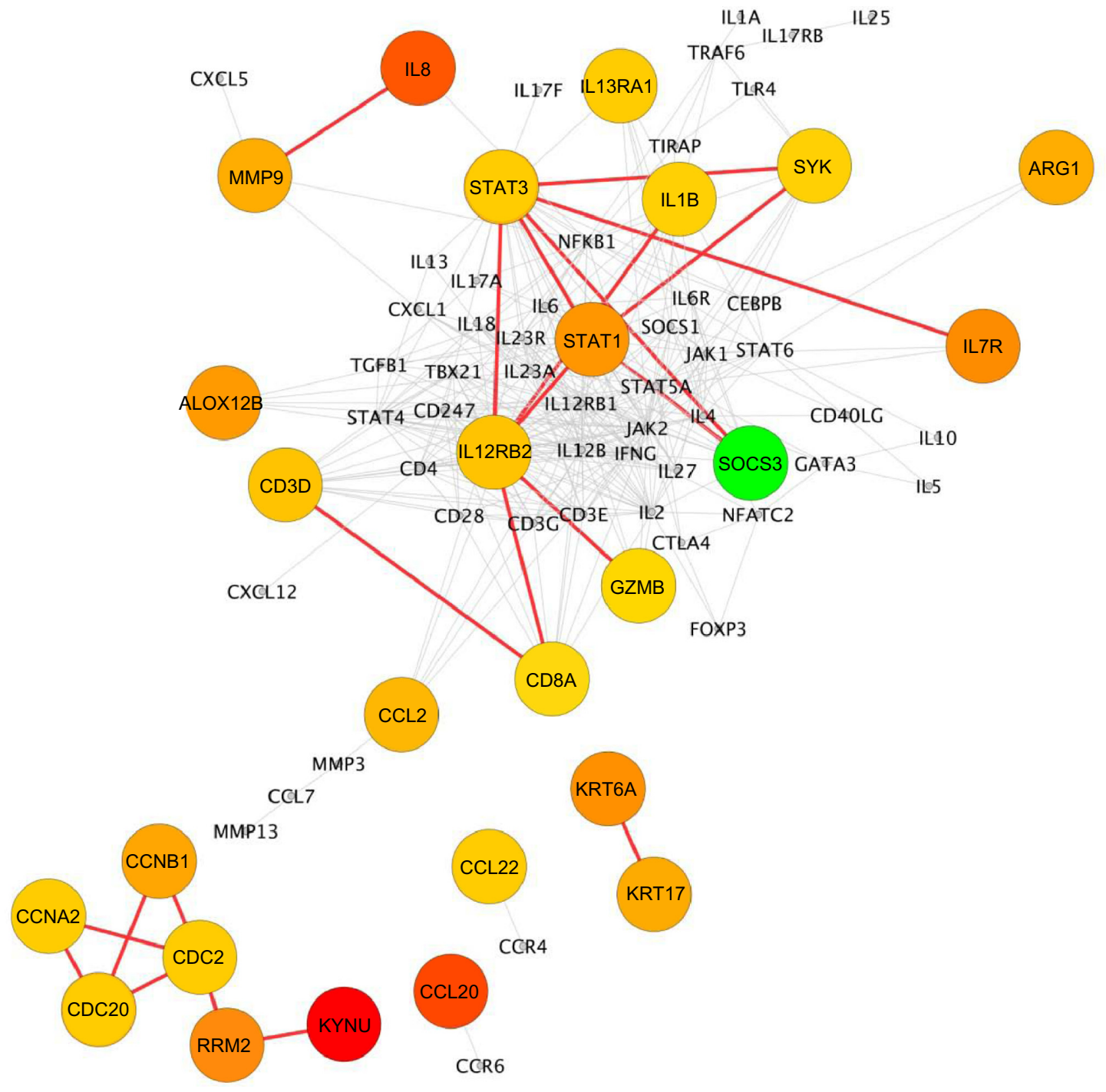

Figure 2 Network analysis (netAnalyse.py method, setting shortest path threshold $=I$ and $P$-value threshold $=0.05$ ) shows possible interaction between the potential gene targets for treatment of psoriasis as identified in this study. Green circles indicate downregulated genes, orange/red circles indicate upregulated genes and small gray circles indicate part of the T helper 17/regulatory T cell pathway, but were not found to be affected in the experiments analyzed in this study. Lines between nodes show known direct interactions between genes. The network was edited in Cytoskape, with a force-directed layout applied. Nodes showing affected genes were enlarged and direct interactions between these nodes were highlighted in red to highlight the relevant interactions identified in this analysis in the context of the $\mathrm{T}$ helper I7/regulatory $\mathrm{T}$ cell pathway.

altered expression level as a result of the disease. Moreover, it decreases the chance of drawing incorrect conclusions because the data are not generated from one laboratory. In 2005, Irizarry et $\mathrm{al}^{27}$ demonstrated that there are relatively large differences in data obtained from different laboratories, even between those using the same platform, but the results from the best performing laboratories agree rather well.

Genes that show significant overexpression in psoriatic skin were functionally annotated on human Kegg pathways (Tables S1 and S2). These genes need further investigation with other techniques and may provide insights into pathogenesis or novel therapeutic targets.

In effect, and despite many efforts, the network of genes that shows significantly altered expression in psoriasis and represents the molecular signature of the disease is still inconspicuous. This is manifested by the relatively high number of recent studies that focused on reanalysis of published data as well as designing new experiments. In 2009, Gudjonsson et al ${ }^{28}$ reported some transcriptional differences between uninvolved skin from psoriatic patients as opposed to skin from normal individuals. Cluster analysis of transcripts with significantly altered expression identified a group of genes involved in lipid metabolism with highly correlated gene expression. Their results suggest decreased lipid biosynthesis and increased innate immunity in uninvolved psoriatic skin.

In 2010, the same group ${ }^{29}$ performed a gene expression study of 58 paired lesional and uninvolved psoriatic and 64 control skin samples. Comparison of involved psoriatic and 
normal skin identified new differentially regulated transcripts. Enriched gene ontology categories included immune response, defense response, and keratinocyte differentiation. In 2012, Tian et $\mathrm{al}^{30}$ adopted a statistically-based meta-analytic approach, which combines the results of individual studies to overcome the problem of having different lists of differentially expressed genes across experiments due to variations introduced in the microarray pipelines. Their method differs from our approach since we have not combined the disparate microarray studies to derive a single estimate of the overall differential expression level for each gene. Instead, we reanalyzed each individual experiment using the same tools and criteria and listed the differentially expressed genes found in common to overcome the problem of getting false positives. The list of differentially expressed genes found in common is a limited set, and in particular, is limited only to genes featured on the less comprehensive array platform (GPL96 Affymetrix Human Genome U133A GeneChip). Combining data from different experiments into one pool is confounded by the inherent differences in platforms and probe sets and the effects of laboratory conditions. Further, our approach was notably different from others in that we extended our search to test a clinical hypothesis that altered transcriptional activity of the genes controlling the active interplay between $T_{H} 17$ and $T_{\text {Reg }}$ cells is important in disease expression.

This contemporary paradigm for psoriasis is supported by other recent studies. Krueger et $\mathrm{al}^{31}$ investigated the effect that neutralization of the $\mathrm{T}_{\mathrm{H}} 17$ cell cytokine, IL-17, has on the clinical features of psoriasis using quantitative real-time polymerase chain reaction and microarrays. Their results suggest that IL-17 is a key "driver" cytokine that activates pathogenic inflammation in psoriatic subjects. They also highlighted that neutralizing IL-17 with the anti-IL-17 monoclonal antibody, ixekizumab, might be a successful therapeutic strategy in psoriasis. ${ }^{31}$ Concomitantly, two studies ${ }^{32,33}$ have been published in which the gene expression signature was used to stratify lesions and reveal distinct molecular subgroups within the clinical phenotype of plaque psoriasis. This is a new direction that will be very important in developing personalized medication for chronic disease.

Our study is also focused on expression of the genes underlying the balance between $\mathrm{T}_{\mathrm{H}} 17$ and $\mathrm{T}_{\mathrm{Reg}}$ cells. Signal transducer and activator of transcription (STAT3, a member of the JAK-STAT signaling pathway), and the chemokines IL-8 and chemokine (C-C motif) ligand 20 (CCL20) were found to be upregulated in the three experiments. These results are in accordance with previously published data. ${ }^{34-36}$ Recently, Miyoshi et $\mathrm{al}^{37}$ showed that use of STA-21, a small
STAT3 inhibitor, was useful in ameliorating psoriatic skin lesions, not only in K5.Stat3C transgenic mice but also in humans. These results emphasize the importance of targeting STAT3 in the quest for new treatments of psoriasis. Similarly, ABX-IL8 is a fully human $\operatorname{IgG}_{2}$ monoclonal antibody that binds to human IL-8 with high affinity and specificity and is currently in Phase II clinical investigation for treatment of psoriasis by Abgenix (Fremont, CA, USA). ${ }^{38}$ Strikingly, Kim et $\mathrm{al}^{39}$ found that pretreatment with fluvastatin and simvastatin inhibited migration of human $\mathrm{CD}^{+} \mathrm{T}$ cells towards CCL20 in a chemotaxis migration assay. These findings suggest that these drugs may be of benefit in alleviating psoriasis via interrupting the CCL20/chemokine receptor 6 (CCR6) chemotactic interaction, thus inhibiting infiltration of $\mathrm{T}_{\mathrm{H}} 17$ cells.

Other chemokines known to be related to $T_{H} 17$ and $T_{\text {Reg }}$ signaling pathways and found to be differentially upregulated in lesional skin samples in at least one of the three experiments are CCL2, CCL22, chemokine (C-X-C motif) ligand 2 (CXCL2), and matrix metallopeptidase 9 (MMP9). CCL2 is expressed by keratinocytes in both atopic dermatitis and psoriasis and when stimulated with TNF- $\alpha$ and/or interferon gamma (IFN- $\gamma$ ) in a dose-dependent manner. ${ }^{40}$ CCL2 binds to the chemokine receptor CCR2 on monocytes and macrophages. CCR2 is overexpressed in monocytes from patients with psoriasis and atopic dermatitis. Thus, CCL2 and CCR2 interaction is likely to be of importance for monocyte/ macrophage trafficking.

CCL22 also belongs to the C-C motif family and is synthesized and secreted by macrophages, dendritic cells, and osteoclasts. It acts selectively on chronically activated lymphocytes by interacting with the CCR4 receptor. Traditionally, CCR4 has been reported to be expressed preferentially on $\mathrm{T}$ cells belonging to the Th2 subpopulation. Recent studies have also shown expression of CCR 4 on $\mathrm{T}_{\mathrm{H}} 17$ cells as well as on $\mathrm{T}_{\text {Reg }}$ cells. ${ }^{41}$ The macrophage-derived chemokine/CCL22 was found to be elevated in the synovial fluid of patients with rheumatoid arthritis and psoriatic arthritis, suggesting that CCR4 could play a role in attracting skin-specific memory T cells to the joints. ${ }^{42}$

MMP9 belongs to a family of proteolytic enzymes that are capable of degrading all components of the extracellular matrix, a key event in the development of cartilage destruction and joint erosion, and may play a part in psoriatic arthritis. In 2006, Cordiali-Fei et $\mathrm{a}^{43}$ observed that MMP9 was decreased, along with clinical improvement in the lesional skin and sera of psoriatic patients receiving infliximab, the anti-TNF- $\alpha$ monoclonal antibody. MMP9 may directly sustain the 
inflammatory process and tissue destruction or contribute by allowing the traffic of inflammatory cells and enhancing the activity of inflammatory cytokines.

CXCL2 was reported to increase by two-fold in psoriatic versus atopic dermatitis skin. ${ }^{44}$ Bowcock and Cookson ${ }^{44}$ proposed that the higher expression of chemokines in psoriasis is among other factors that could sustain chronic $\mathrm{T}$ cell activation and persistence within focal skin regions.

Interestingly, our analysis did not show that all genes relating to the $\mathrm{T}_{\mathrm{H}} 17$ network (listed in Table 1) are differentially expressed in lesional skin. In another similar study ${ }^{26}$ where comparison of the expression of psoriasis-related genes across four different studies was conducted, some well recognized inflammatory genes involved in psoriasis, for example, IFN- $\gamma$, IL-17, and inducible nitric oxide synthase, were not detected. Using separate polymerase chain reaction, the authors showed that this may be due to low amplification of these genes on the Affymetrix gene array platform ( $0-4$ range of expression in $\log _{2}$ scale), and hence fold change is not accurately measured. As a positive control, this false negative finding suggests caution in interpreting gene array data. Most analysis pipelines filter out low abundance genes so they may be excluded from the statistical analysis, or the resultant fold change is very low, albeit significant. This is a major limitation of the use of these arrays for the study of these genes. Another possible explanation is that the expression was measured in bulk skin samples containing numerous cell types, and most of these genes are expressed in multiple cell types, so upregulation of a certain gene in one cell type may be neutralized by downregulation in another cell type. $^{32}$

CD34, CD3D, and CD8A are the only surface receptor genes from the list in Table 1 that were found to be differentially expressed in psoriatic lesions. CD34 was found in one experiment to be downregulated in lesional versus nonlesional skin (Table 2).

In our analysis, both CD3D and CD8A were found to be upregulated in lesional versus nonlesional skin. Both genes were previously reported to be downregulated in patients responding to alefacept, the LFA3-Ig fusion protein that binds to CD2. ${ }^{45}$

Other genes upregulated in our analysis (listed in Table 1) are IL- $1 \beta$ and IL-7R. In a previous study, ${ }^{46}$ IL-1 $\beta$ was easily detectable by immunofluorescence microscopy and found to be localized predominantly in epidermal keratinocytes. Immunoreactive IL-1 $\beta$ was found to be elevated in cytosolic extracts derived from involved psoriatic keratomes relative to keratomes of normal skin. The elevated IL-1 $\beta$ protein was accompanied by elevated levels of IL-1 $\beta$ mRNA in psoriatic skin relative to normal skin. IL-7R expression is also known to increase by at least a two-fold magnitude in the peripheral blood cells of psoriatic patients when measured by cDNA microarray technology. ${ }^{47}$

\section{Conclusion}

Studies of gene expression profiling have the potential to greatly improve our understanding of the physiologic and molecular mechanisms underlying the pathogenesis and progression of psoriasis. However, the high chance of getting false positives has become a concern. Reanalysis of data extracted from different experiments using the same software and stringent criteria could reduce this risk and thus refine the list of proposed new therapeutic targets. Our study also highlights the altered expression of genes known to be involved in the control of the $T_{H} 17 / T_{\text {Reg }}$ balance in psoriatic skin. By reanalyzing repository data and specifically querying these pathways, we provide further evidence that this balance is of key importance in the etiopathogenesis and progression of psoriasis and demonstrate another approach to mining this data.

\section{Acknowledgment}

We would like to thank Dr Claus Mayer of the Rowett Institute of Nutrition and Health at University of Aberdeen and Dr Elaina SR Collie-Duguid of the Institute of Medical Sciences at University of Aberdeen for their fruitful discussions.

\section{Disclosure}

The authors declare that they have no competing interests in this work.

\section{References}

1. Bowcock AM, Krueger JG. Getting under the skin: the immunogenetics of psoriasis. Nat Rev Immunol. 2005;5:699-711.

2. Lowes MA, Bowcock AM, Krueger JG. Pathogenesis and therapy of psoriasis. Nature. 2007;445:866-873.

3. Bachelez H. Immunopathogenesis of psoriasis: recent insights on the role of adaptive and innate immunity. J Autoimmun. 2005;25:69-73.

4. Oestreicher JL, Walters IB, Kikuchi T, et al. Molecular classification of psoriasis disease-associated genes through pharmacogenomic expression profiling. Pharmacogenomics. 2001;1:272-287.

5. Bowcock AM, Shannon W, Du F, et al. Insights into psoriasis and other inflammatory diseases from large-scale gene expression studies. Hum Mol Genet. 2001;10:1793-1805.

6. Zhou X, Krueger JG, Kao MJ, et al. Novel mechanisms of T-cell and dendritic cell activation revealed by profiling of psoriasis on the $63,100-$ element oligonucteotide array. Physiol Genomics. 2003;13:69-78.

7. Quekenborn-Trinquet V, Fogel P, Aldana-Jammayrac O, et al. Gene expression profiles in psoriasis: analysis of impact of body site location and clinical severity. Br J Dermatol. 2005;152:489-504.

8. Reischl J, Schwenke S, Beekman JM, et al. Increased expression of Wnt5a in psoriatic plaques. J Invest Dermatol. 2007;127:163-169. 
9. Wu J, Lenchik NI, Gerling IC. Approaches to reduce false positives and false negatives in the analysis of microarray data: applications in type 1 diabetes research. BMC Genomics. 2008;9 Suppl 2:S12.

10. Mai J, Wang H, Yang X. Th17 cells interplay with FOXP3 Tregs in regulation of inflammation and autoimmunity. Front Biosci. 2011;15:986-1006.

11. Haider AS, Lowes MA, Suàrez-Fariñas M, et al. Identification of cellular pathways of "Type 1," Th17 T Cells, and TNF- and inducible nitric oxide synthase-producing dendritic cells in autoimmune inflammation through pharmacogenomic study of cyclosporine A in psoriasis. J Immunol. 2008;180:1913-1920.

12. Vignali DA, Collison LW, Workman CJ. How regulatory T cells work. Nat Rev Immunol. 2008;8:523-532.

13. Pasare C, Medzhitov R. Toll pathway-dependent blockade of $\mathrm{CD} 4^{+} \mathrm{CD} 25^{+} \mathrm{T}$ cell-mediated suppression by dendritic cells. Science. 2003;299:1033-1036.

14. Korn T, Reddy J, Gao W, et al. Myelin-specific regulatory T cells accumulate in the CNS but fail to control autoimmune inflammation. Nat Med. 2007;13:423-431.

15. Nair RP, Duffin KC, Helms C, et al. Genome wide scan reveals association of psoriasis with IL-23 and NF-אB pathways. Nat Genet. 2009;41: 199-204.

16. Yao Y, Richman L, Morehouse C, et al. Type I interferon: potential therapeutic target for psoriasis? PLoS One. 2008;16:e2737.

17. Huang W, Sherman BT, Lempicki, RA. Systematic and integrative analysis of large gene lists using DAVID bioinformatics resources. Nat Protoc. 2009;4:44-57.

18. Keshava PrasadTS, Goel R, Kandasamy K, et al. Human protein reference database-2009 update. Nucleic Acids Res. 2009;37:D767-D772.

19. Joshi-Tope G, Gillespie M, Vastrik I, et al. Reactome: a knowledgebase of biological pathways. Nucleic Acids Res. 2005;33:D428-D432.

20. Matthews L, Gopinath G, Gillespie M, et al. Reactome knowledgebase of human biological pathways and processes. Nucleic Acids Res. 2009;37:D619-D622.

21. Schaefer CF, Anthony K, Krupa S, et al. PID: the Pathway Interaction Database. Nucleic Acids Res. 2009;37:D674-D679.

22. Cerami E, Demir E, Schultz N, Taylor BS, Sander C. Automated network analysis identifies core pathways in glioblastoma. PLoS One. 2010;5:e8918.

23. Shannon P, Markiel A, Ozier O, Baliga NS, et al. Cytoscape: a software environment for integrated models of biomolecular interaction networks. Genome Res. 2003;13:2498-2504.

24. Awasthi A, Murugaiyan G, Kuchroo VK. Interplay between effector Th17 and regulatory T cells. J Clin Immunol. 2008;28:660-670.

25. Suárez-Fariñas M, Magnasco MO. Comparing microarray studies. Methods Mol Biol. 2007;377:139-152.

26. Suárez-Fariñas M, Lowes MA, Zaba LC, Krueger JG. Evaluation of the psoriasis transcriptome across different studies by gene set enrichment analysis (GSEA). PLoS One. 2010;5:e10247.

27. Irizarry RA, Warren D, Spencer F, et al. Multiple-laboratory comparison of microarray platforms. Nat Methods. 2005;2:345-350.

28. Gudjonsson JE, Ding J, Li X, et al. Global gene expression analysis reveals evidence for decreased lipid biosynthesis and increased innate immunity in uninvolved psoriatic skin. J Invest Dermatol. 2009;129: 2795-2804

29. Gudjonsson JE, Ding J, Johnston A, et al. Assessment of the psoriatic transcriptome in a large sample: additional regulated genes and comparisons with in vitro models. J Invest Dermatol. 2010;130: 1829-1840
30. Tian S, Krueger JG, Li K, et al. Meta-analysis derived (MAD) transcriptome of psoriasis defines the "core" pathogenesis of disease. PLoS One. 2012;7:e44274.

31. Krueger JG, Fretzin S, Suárez-Fariñas M, et al. IL-17A is essential for cell activation and inflammatory gene circuits in subjects with psoriasis. J Allergy Clin Immunol. 2012;130:145-154.

32. Swindell WR, Xing X, Stuart PE, et al. Heterogeneity of inflammatory and cytokine networks in chronic plaque psoriasis. PLoS One. 2012;7:e34594.

33. Ainali C, Valeyev N, Perera G, et al. Transcriptome classification reveals molecular subtypes in psoriasis. BMC Genomics. 2012;13:472.

34. Sano S, Chan KS, DiGiovanni J. Impact of Stat 3 activation upon skin biology: a dichotomy of its role between homeostasis and diseases. J Dermatol Sci. 2008;50:1-14.

35. Homey B, Dieu-Nosjean M, Wiesenborn A, et al. Up-regulation of macrophage inflammatory protein-3 $\alpha /$ CCL20 and CC chemokine receptor 6 in psoriasis. J Immunol. 2011;164:6621-6632.

36. Schulz BS, Michel G, Wagner S, et al. Increased expression of epidermal IL-8 receptor in psoriasis: down-regulation by FK-506 in vitro. J Immunol. 1993;151:4399-4406.

37. Miyoshi K, Takaishi M, Nakajima K, et al. Stat3 as a therapeutic target for the treatment of psoriasis: a clinical feasibility study with STA-21, a Stat3 inhibitor. J Invest Dermatol. 2011;131:108-117.

38. Wang B, Roskos L, Osborn K, et al. A population pharmacokinetic (PK) analysis of ABX-IL8, a fully human monoclonal IGG2 antibody, in psoriasis patients. Clin Pharmacol Ther. 2005;77:P91.

39. Kim T, Byamba D, Wu WH, Lee M. Statins inhibit chemotactic interaction between CCL20 and CCR6 in vitro: possible relevance to psoriasis treatment. Exp Dermatol. 2011;20:855-857.

40. Vestergaard C, Just H, Baumgartner NJ, et al. Expression of CCR2 on monocytes and macrophages in chronically inflamed skin in atopic dermatitis and psoriasis. Acta Derm Venereol. 2004;84: 353-558.

41. Lim HW, Lee J, Hillsamer P, Kim CH. Human Th17 cells share major trafficking receptors with both polarized effector T cells and FOXP3 ${ }^{+}$ regulatory T cells. J Immunol. 2008;180:122-129.

42. Flytlie AA, Hvid M, Lindgreen E, et al. Expression of MDC/CCL22 and its receptor CCR4 in rheumatoid arthritis, psoriatic arthritis and osteoarthritis. Cytokine. 2010;49:24-29.

43. Cordiali-Fei P, Trento E, D'Agosto G, et al. Decreased levels of metalloproteinase- 9 and angiogenic factors in skin lesions of patients with psoriatic arthritis after therapy with anti-TNF- $\alpha$. J Autoimmune Dis. 2006;5:3-5.

44. Bowcock AM, Cookson WO. The genetics of psoriasis, psoriatic arthritis and atopic dermatitis. Hum Mol Genet. 2004;13:R43-R55.

45. Haider AS, Lowes MA, Gardner H, et al. Novel insight into the agonistic mechanism of Alefacept in vivo: differentially expressed genes may serve as biomarkers of response in psoriasis patients. J Immunol. 2007; 178:7442-7449.

46. Cooper KD, Hammerberg C, Baadsgaard O, et al. IL-1 activity is reduces in psoriatic skin. Decreased IL-1 $\alpha$ and increased non-functional IL-1 $\beta$. J Immunol. 1990;144:4593-4603.

47. Lee S, Jeon E, Kim Y, et al. A global gene expression analysis of the peripheral blood mononuclear cells reveals the gene expression signature in psoriasis. Ann Dermatol. 2009;21:237-242. 


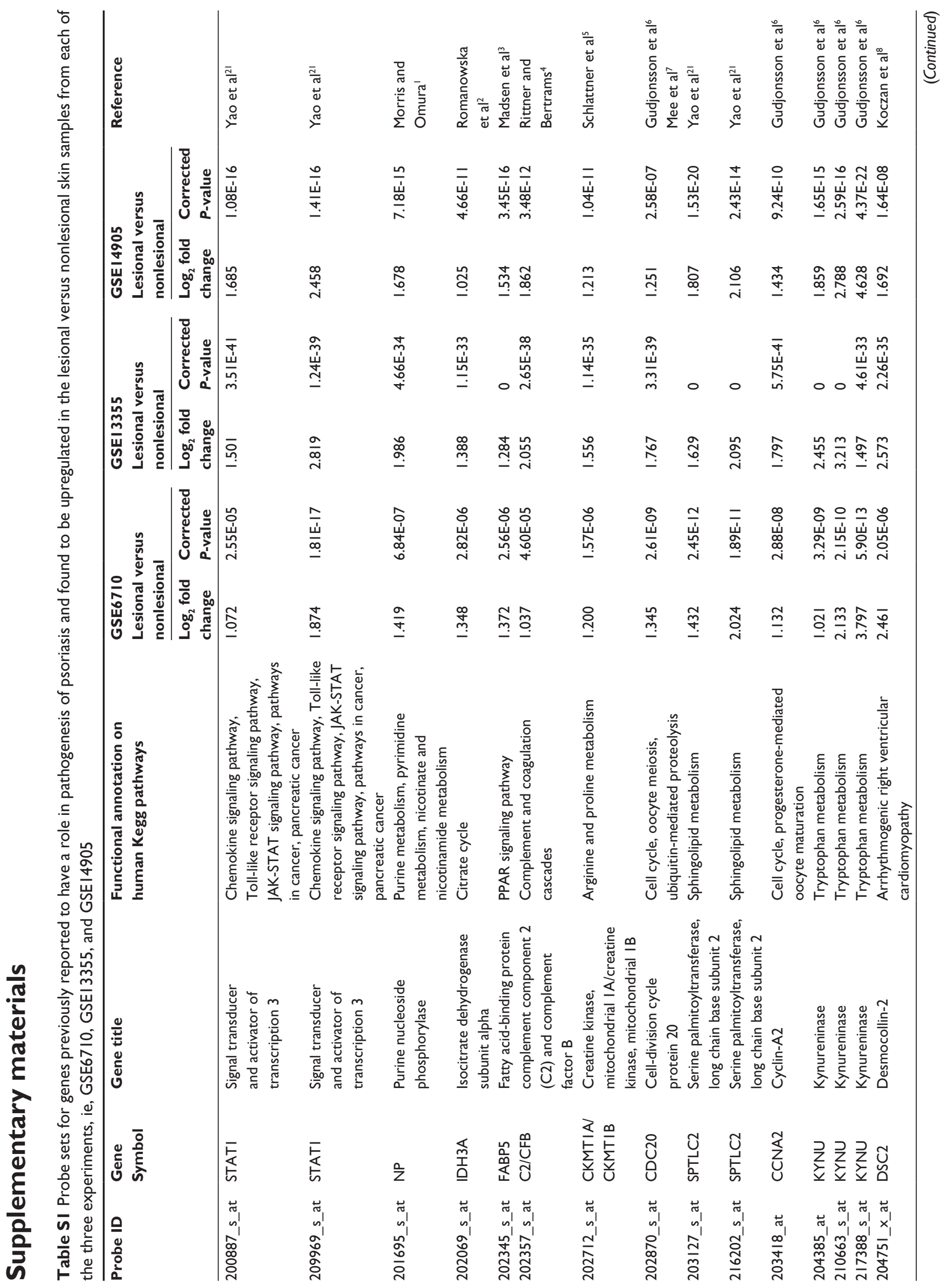




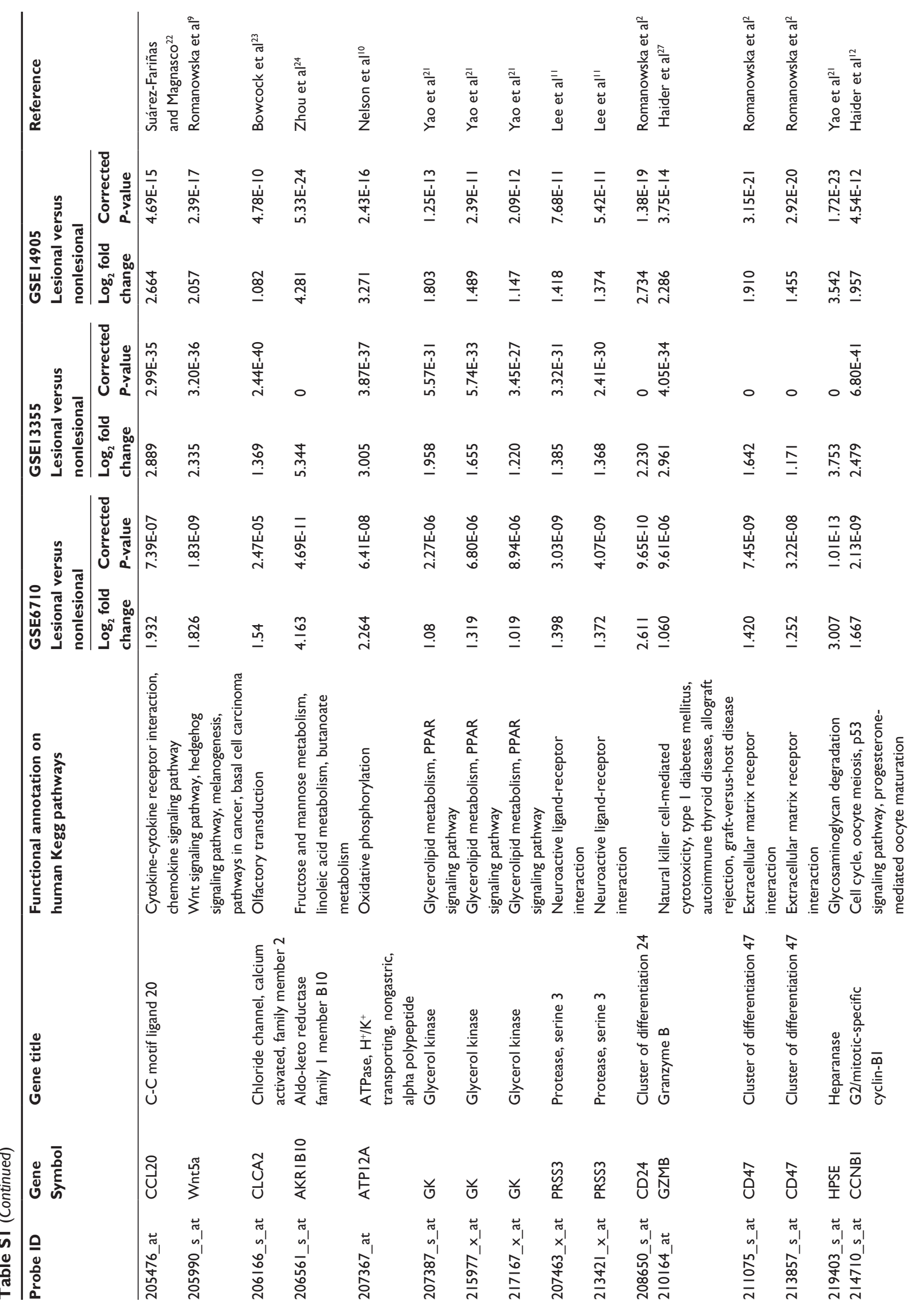




\begin{tabular}{|c|c|c|c|c|c|c|c|c|c|c|c|c|c|}
\hline 彥 & 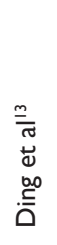 & 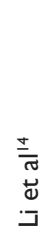 & 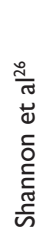 & 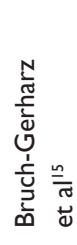 & 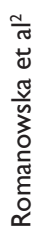 & 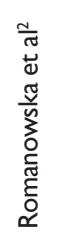 & 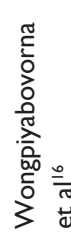 & 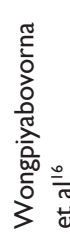 & 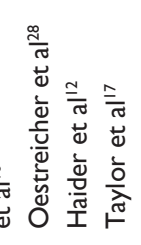 & 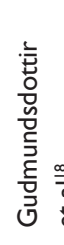 & 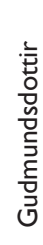 & & 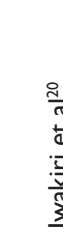 \\
\hline & $\overline{\bar{u}}$ & 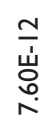 & $\frac{\stackrel{N}{\dot{H}}}{\bar{m}}$ & 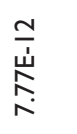 & $\overline{\bar{u}}$ & 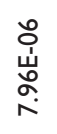 & 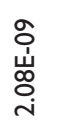 & $\begin{array}{c}\overline{\dot{u}} \\
\stackrel{\sim}{\stackrel{\sigma}{*}}\end{array}$ & 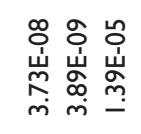 & 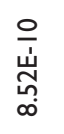 & 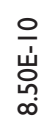 & & ؟ \\
\hline & $\stackrel{\hat{q}}{\underline{q}}$ & 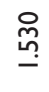 & $\stackrel{\bar{T}}{\underline{I}}$ & 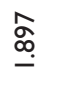 & $\underline{\underline{\alpha}}$ & $\stackrel{\text { o }}{\stackrel{\text { fo }}{.}}$ & $\underset{+}{\stackrel{+}{+}}$ & 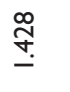 & 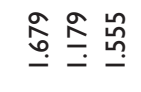 & $\stackrel{\leftrightarrow}{\circ}$ & $\underline{\underline{\underline{n}}}$ & & o \\
\hline & 离 & 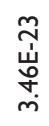 & 离 & 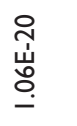 & 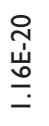 & $\frac{\frac{\sigma}{\dot{u}}}{\frac{\sigma}{\dot{\alpha}}}$ & 突 & 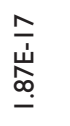 & 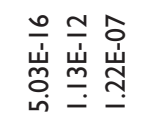 & 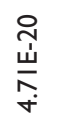 & 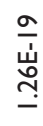 & & 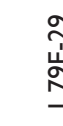 \\
\hline & 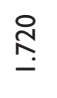 & 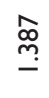 & $\stackrel{\text { 음 }}{\underline{-}}$ & $\overline{\bar{s}}$ & 宓 & $\stackrel{\sim}{\grave{i}}$ & $\stackrel{\stackrel{n}{m}}{\underline{n}}$ & $\stackrel{\infty}{\stackrel{0}{\circ}}$ & 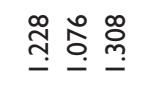 & $\stackrel{\substack{0 \\
\hdashline}}{-}$ & $\stackrel{\stackrel{2}{\cong}}{=}$ & & $\stackrel{\infty}{\beth}$ \\
\hline & 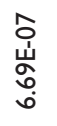 & חo & 0 & 总 & 员 & $\begin{array}{l}\stackrel{\circ}{1} \\
\stackrel{\leftrightarrow}{\leftrightarrow} \\
\text { i }\end{array}$ & 苍 & 0 & 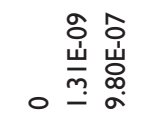 & 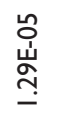 & ठั & & g \\
\hline & $\underset{\mathfrak{T}}{0}$ & $\stackrel{\stackrel{\circ}{ }}{=}$ & $\underline{\bar{\alpha}}$ & 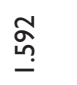 & $\stackrel{\vec{y}}{=}$ & $\underset{\mathbb{N}}{\underline{S}}$ & ָ̣̊̊ & 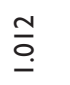 & 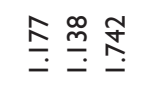 & 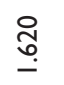 & & & 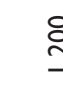 \\
\hline
\end{tabular}
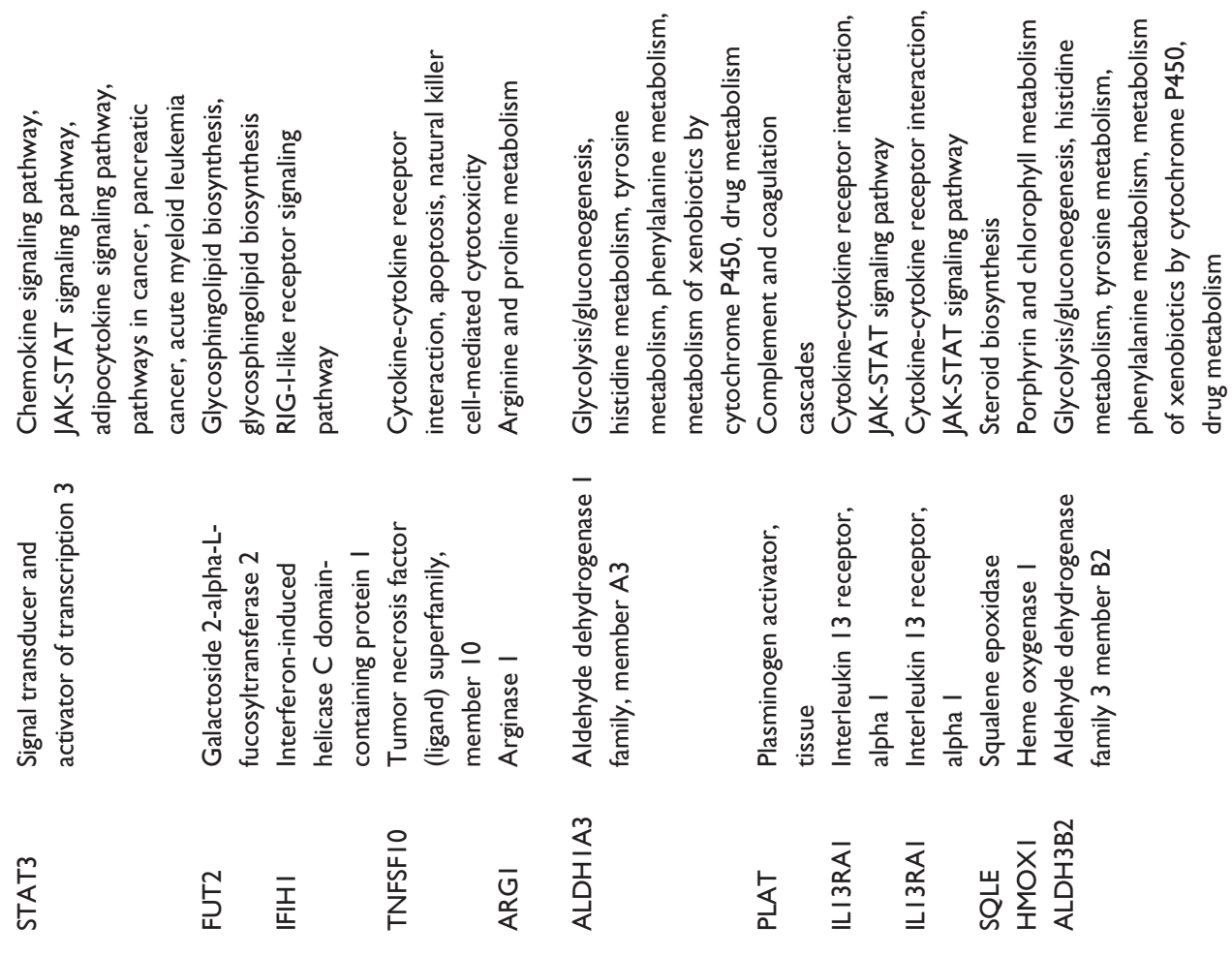

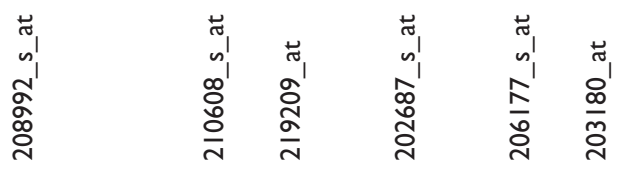
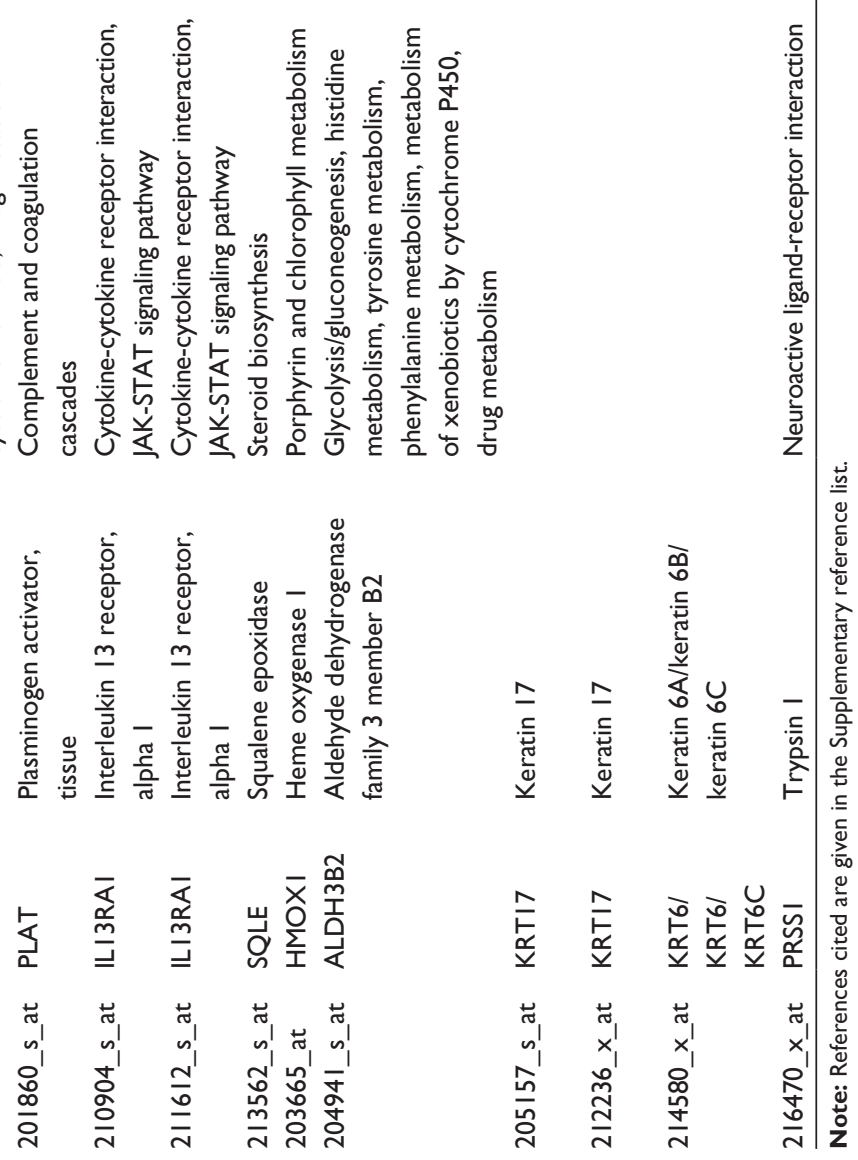


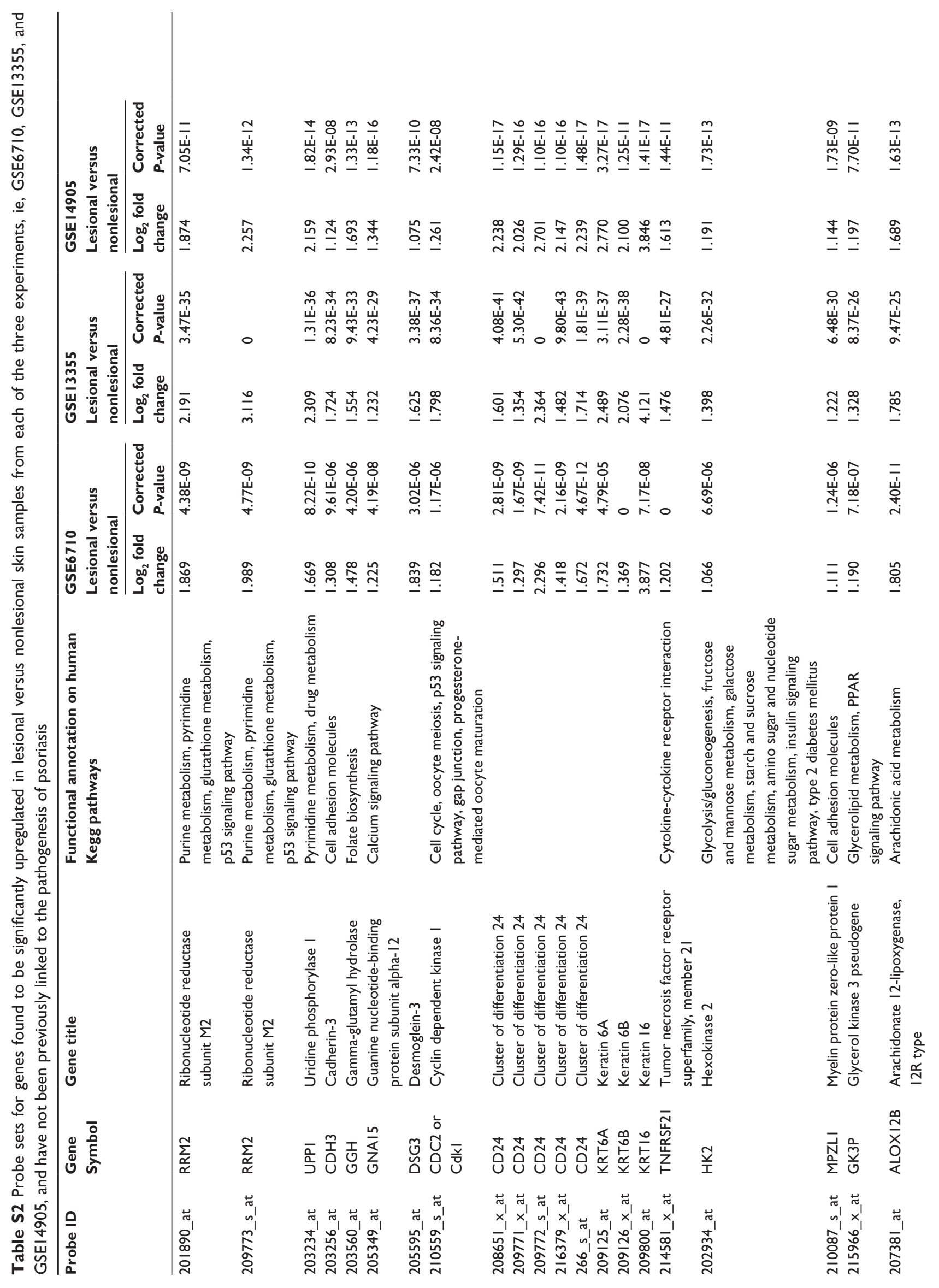




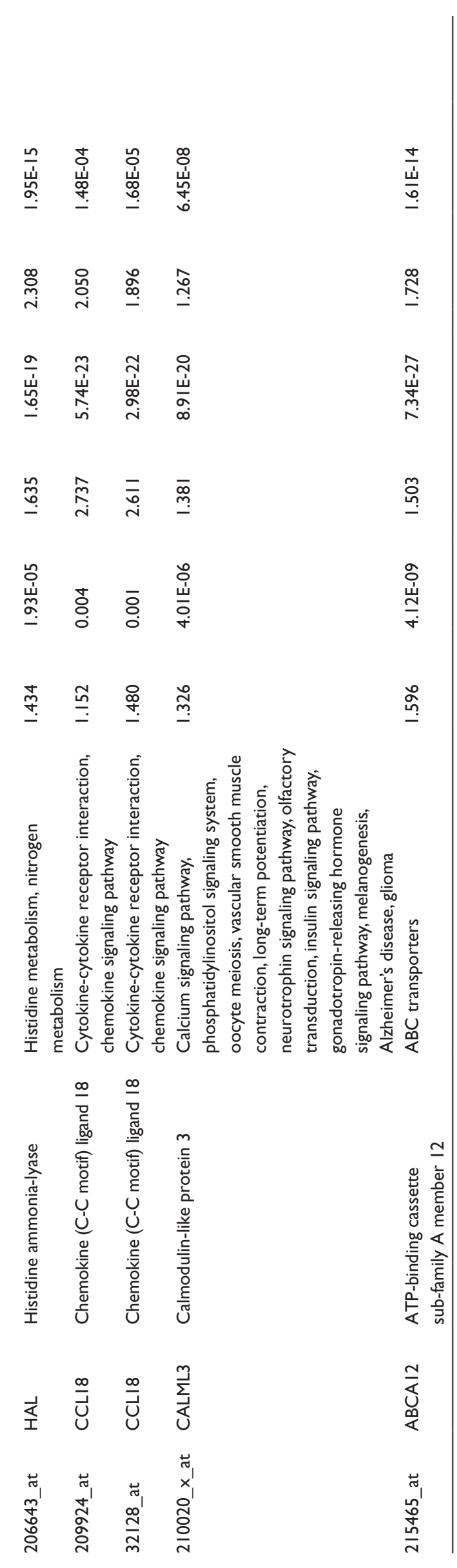




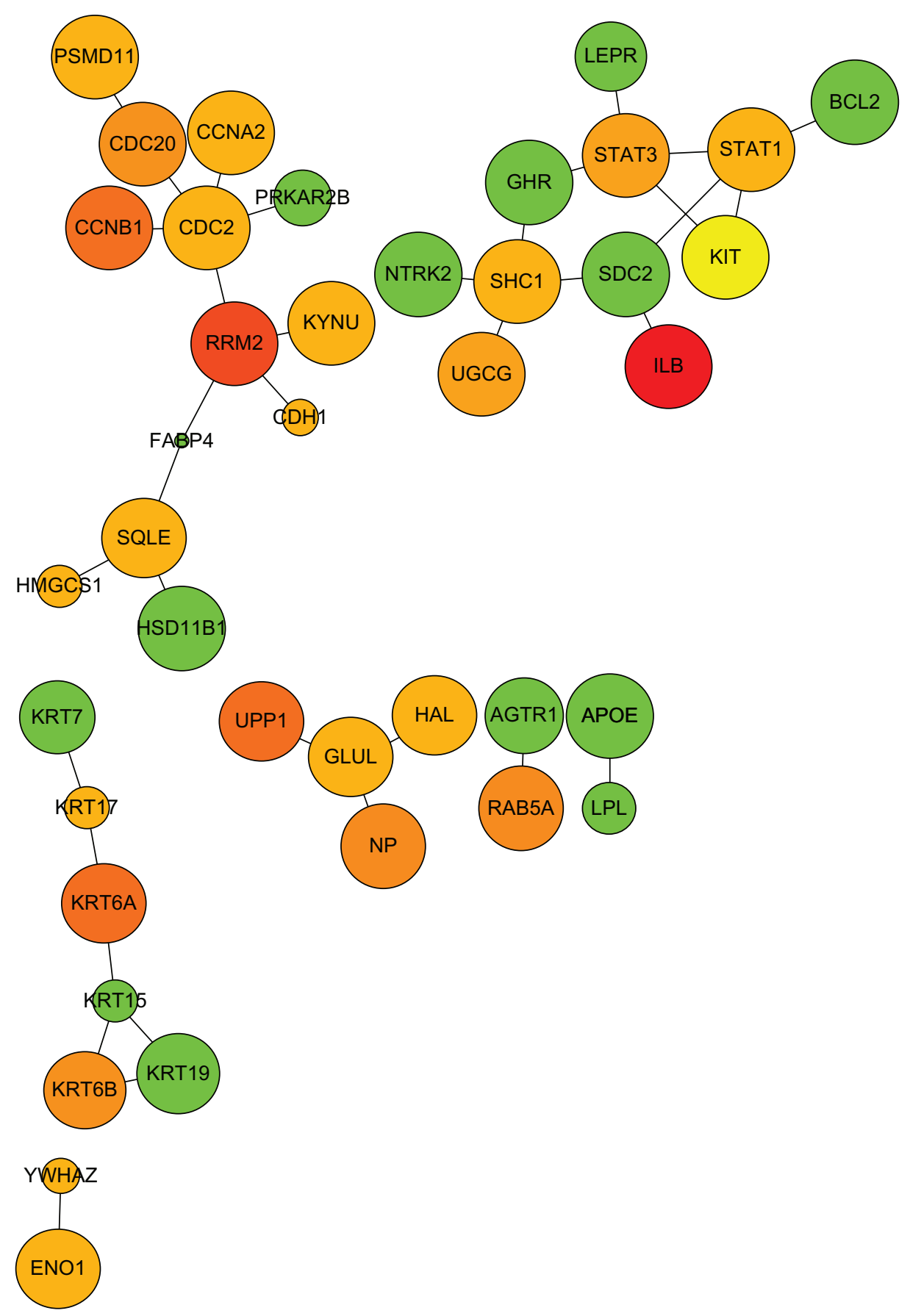

Figure SI Network analysis (netAnalyse.py method, setting shortest path threshold $=I$ and $P$-value threshold $=0.05$ ) shows possible interaction between the potential gene targets for treatment of psoriasis as identified in this study from the GSE67I0 experiment. ${ }^{29}$ The network was edited in Cytoskape, with a force-directed layout applied. Green circles indicate downregulated genes, yellow-orange-red circles indicate upregulated genes, with red showing strongest and yellow showing least upregulation. Size of the nodes indicates the level of significance, with larger nodes showing a lower FDR (higher significance). Lines connecting nodes show direct interactions between genes. 


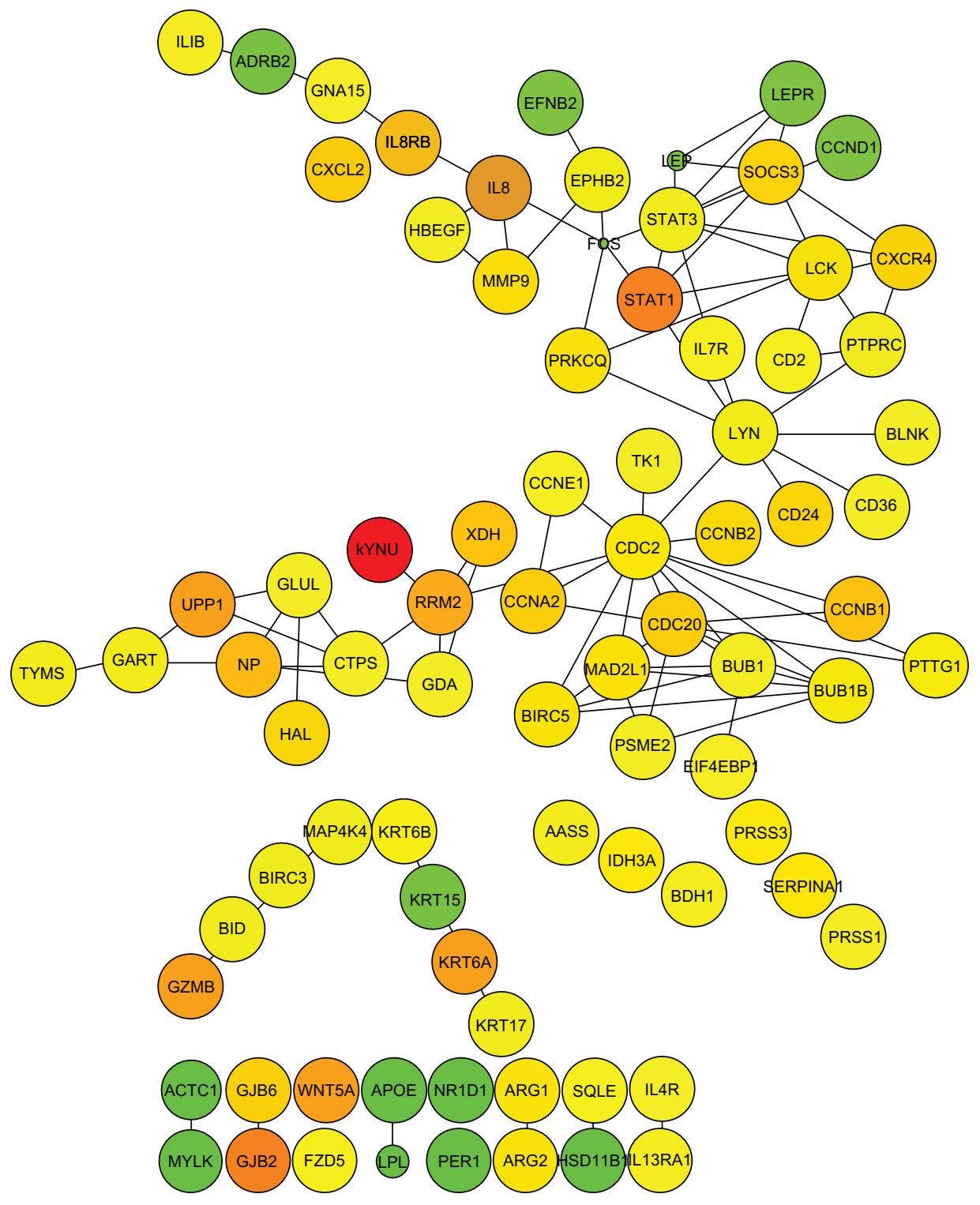

Figure S2 Network analysis (netAnalyse.py method, setting shortest path threshold $=I$ and $P$-value threshold $=0.05$ ) shows possible interaction between potential gene targets for the treatment of psoriasis as identified in this study from the GSEI3355 experiment. ${ }^{30}$ The network was edited in Cytoskape, with a force-directed layout applied. Green circles indicate downregulated genes, yellow-orange-red circles indicate upregulated genes, with red showing strongest and yellow showing least upregulation. Size of the nodes indicates the level of significance, with larger nodes showing a lower FDR (higher significance). Lines connecting nodes show direct interactions between genes. 


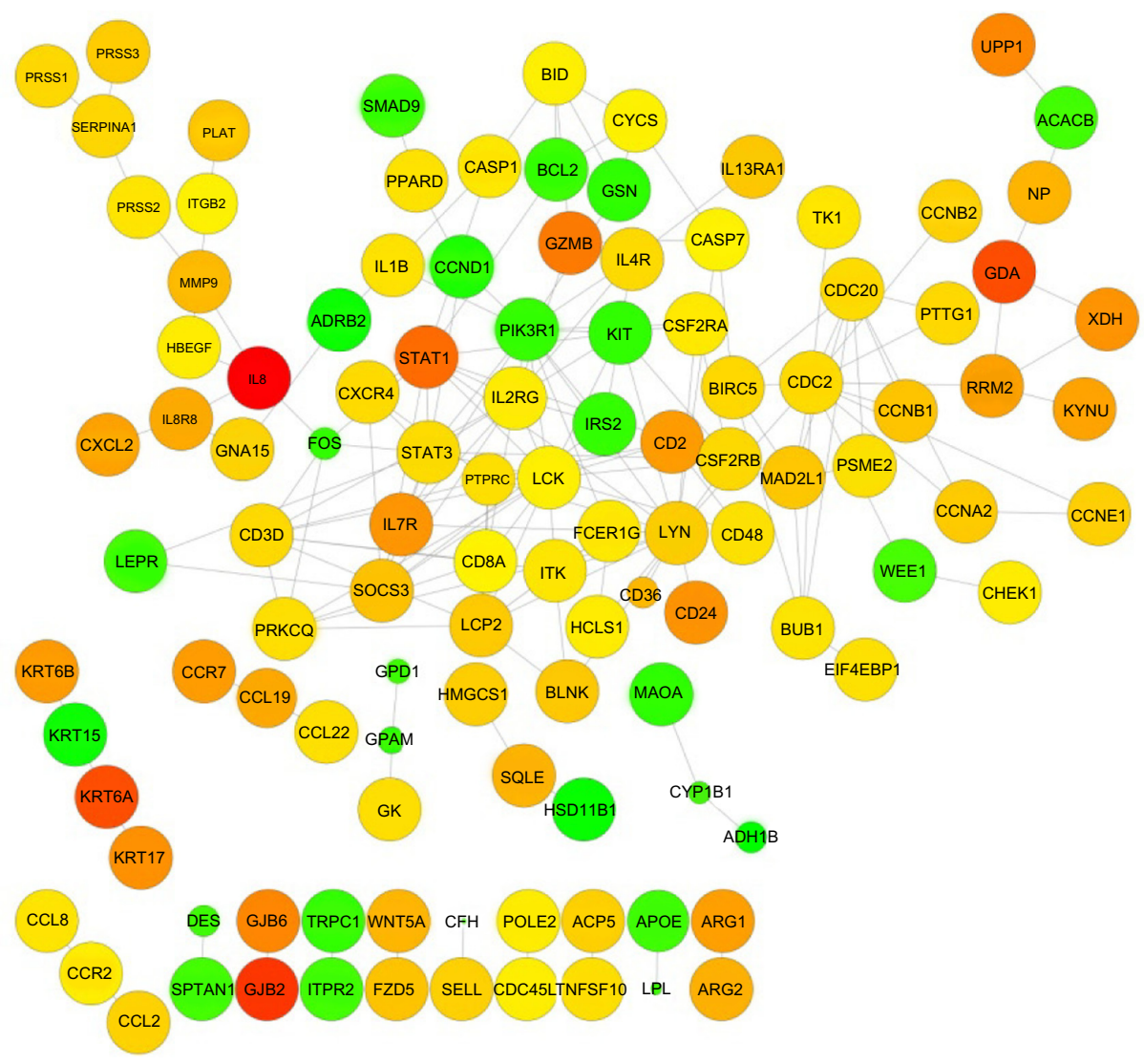

Figure S3 Network analysis shows possible interaction between the potential gene targets for the treatment of psoriasis as identified in this study from the GSEI4905 experiment ${ }^{21}$ (green circles indicate downregulated genes and orange/red circles indicate upregulated genes).

\section{References}

1. Morris PE, Omura GA. Inhibitors of the enzyme purine nucleoside phosphorylase as potential therapy for psoriasis. Curr Pharm Des. 2000;6:943-959.

2. Romanowska M, Yacoub NA, Seidel H, et al. PPAR $\delta$ enhances keratinocyte proliferation in psoriasis and induces heparin-binding EGFlike growth factor. J Invest Dermatol. 2008;128:110-124.

3. Madsen P, Rasmussen HH, Leffers H, Honoré B, Celis JE. Molecular cloning and expression of a novel keratinocyte protein (psoriasisassociated fatty acid-binding protein [PA-FABP]) that is highly upregulated in psoriatic skin and that shares similarity to fatty acid-binding proteins. J Invest Dermatol. 1992;99:299-305.

4. Rittner C, Bertrams J. On the significance of $\mathrm{C} 2, \mathrm{C} 4$, and factor B polymorphisms in disease. Hum Genet. 1981;56:235-247.

5. Schlattner U, Möckli N, Speer O, Werner S, Wallimann T. Creatine kinase and creatine transporter in normal, wounded, and diseased skin. J Invest Dermatol. 2002;118:416-423.

6. Gudjonsson JE, Ding J, Johnston A, et al. Assessment of the psoriatic transcriptome in a large sample: additional regulated genes and comparisons with in vitro models. $J$ Invest Dermatol. 2010;130:1829-1840.

7. Mee JB, Johnson CM, Morar N, Burslem F, Groves RW. The psoriatic transcriptome closely resembles that induced by interleukin-1 in cultured keratinocytes dominance of innate immune responses in psoriasis. Am J Pathol. 2007;171:32-42.

8. Koczan D, Guthke R, Thiesen H, et al. Gene expression profiling of peripheral blood mononuclear leukocytes from psoriasis patients identifies new immune regulatory molecules. Eur J Dermatol. 2005;15:251-257.

9. Romanowska M, Evans A, Kellock D, et al. Wnt5a exhibits layer-specific expression in adult skin, is upregulated in psoriasis, and synergizes with type 1 interferon. PLoS One. 2009;4:e5354.
10. Nelson AM, Zhao W, Gilliland KL, Zaenglein AL, Liu W, Thiboutot DM. Early gene changes induced by isotretinoin in the skin provide clues to its mechanism of action. Dermatoendocrinol. 2009;1:100-101.

11. Lee S, Kim B, Seo S, et al. Gene expression profile in fetal bovine serum-induced abnormal differentiation of skin keratinocytes. Korean J Invest Dermatol. 2006;126:125-133.

12. Haider AS, Peters SB, Kaporis H, et al. Genomic analysis defines a cancer-specific gene expression signature for human squamous cell carcinoma and distinguishes malignant hyperproliferation from benign hyperplasia. J Invest Dermatol. 2006;126:869-881.

13. Ding J, Gudjonsson JE, Liang L, et al. Gene expression in skin and lymphoblastoid cells: refined statistical method reveals extensive overlap in cis-eQTL signals. Am J Hum Genet. 2010;87:779-789.

14. Li Y, Liao W, Cargill M, et al. Carriers of rare missense variants in IFIH1 are protected from psoriasis. J Invest Dermatol. 2010;130: 2768-2772.

15. Bruch-Gerharz D, Schnorr O, Suschek C, et al. Arginase 1 overexpression in psoriasis limitation of inducible nitric oxide synthase activity as a molecular mechanism for keratinocyte hyperproliferation. Am J Pathol. 2003;12:203-211.

16. Wongpiyabovorna J, Sutoa H, Ushiob H, et al. Up-regulation of interleukin-13 receptor a1 on human keratinocytes in the skin of psoriasis and atopic dermatitis. J Dermatol Sci. 2003;33:31-40.

17. Taylor JM, Street TL, Hao L, et al. Dynamic and physical clustering of gene expression during epidermal barrier formation in differentiating keratinocytes. PLoS One. 2009;4:e7651.

18. Gudmundsdottir AS, Sigmundsdottir H, Sigurgeirsson B, Good MF, Valdimarsson H, Jonsdottir I. Is an epitope on keratin 17 a major target for autoreactive T lymphocytes in psoriasis? Clin Exp Immunol. 1999; 117:580-586. 
19. Mommers JM, van Rossum MM, van Erp PE, van De Kerkhof PC. Changes in keratin 6 and keratin 10 (co-)expression in lesional and symptomless skin of spreading psoriasis. Dermatology. 2000;201: $15-20$.

20. Iwakiri K, Ghazizadeh M, Jin E, et al. Human airway trypsin-like protease induces PAR-2-mediated IL- 8 release in psoriasis vulgaris. J Invest Dermatol. 2004;122:937-944.

21. Yao Y, Richman L, Morehouse C, et al. Type I interferon: potential therapeutic target for psoriasis? PLoS One. 2008;16:e2737.

22. Suárez-Fariñas M, Magnasco MO. Comparing microarray studies. Methods Mol Biol. 2007;377:139-152.

23. Bowcock AM, Shannon W, Du F, et al. Insights into psoriasis and other inflammatory diseases from large-scale gene expression studies. Hum Mol Genet. 2001;10:1793-1805.

24. Zhou X, Krueger JG, Kao MJ, et al. Novel mechanisms of T-cell and dendritic cell activation revealed by profiling of psoriasis on the 63,100-element oligonucteotide array. Physiol Genomics. 2003;13:69-78.

25. Irizarry RA, Warren D, Spencer F, et al. Multiple-laboratory comparison of microarray platforms. Nat Methods. 2005;2:345-350.

26. Shannon P, Markiel A, Ozier O, Baliga NS, et al. Cytoscape: a software environment for integrated models of biomolecular interaction networks. Genome Res. 2003;13:2498-2504.
27. Haider AS, Lowes MA, Suàrez-Fariñas M, et al. Identification of cellular pathways of "Type 1," Th17 T Cells, and TNF- and inducible nitric oxide synthase-producing dendritic cells in autoimmune inflammation through pharmacogenomic study of cyclosporine A in psoriasis. $J$ Immunol. 2008;180:1913-1920.

28. Oestreicher JL, Walters IB, Kikuchi T, et al. Molecular classification of psoriasis disease-associated genes through pharmacogenomic expression profiling. Pharmacogenomics. 2001;1:272-287.

29. Reischl J, Schwenke S, Beekman JM, et al. Increased expression of Wnt5a in psoriatic plaques. J Invest Dermatol. 2007;127:163-169.

30. Nair RP, Duffin KC, Helms C, et al. Genome wide scan reveals association of psoriasis with IL-23 and NF-кB pathways. Nat Genet. 2009;41: 199-204.

\section{Publish your work in this journal}

Psoriasis: Targets and Therapy is international, peer-reviewed, open access journal focusing on psoriasis, nail psoriasis, psoriatic arthritis and related conditions, identification of therapeutic targets and the optimal use of integrated treatment interventions to achieve improved outcomes and quality of life. The manuscript management system

\section{Dovepress}

is completely online and includes a very quick and fair peer-review system. Visit http://www.dovepress.com/testimonials.php to read real quotes from published authors. 